Veteriner Farmakoloji ve Toksikoloji Derneği Bülteni

Bulletin of Veterinary Pharmacology and Toxicology Association

e-ISSN 2667-8381, 11 (3): 151-160, 2020

DOI: $10.38137 /$ vetfarmatoksbulten. 799062

\title{
AKUT ZEHİRLİLIKK DENEMELERİ ve ÖLDÜRÜCÜ DOZ 50
}

\author{
Allafouza TIDJANI MAHAMAT ${ }^{\mathrm{a}}$, Levent ALTINTAŞ ${ }^{\mathrm{b}^{*}}$ \\ Ankara Üniversitesi Veteriner Fakültesi Farmakoloji ve Toksikoloji Anabilim Dall, Ankara \\ ORCID $^{\mathrm{a}}$ : 0000-0001-7377-2587, ORCID $^{\mathrm{b}}$ : 0000-0002-5148-723X
}

*Sorumlu Yazar: Levent ALTINTAŞ

E-Posta: laltintas@ankara.edu.tr
Geliş Tarihi: 02.12 .2020

Kabul Tarihi: 16.12 .2020

\section{ÖZET}

İnsanlar varoluşlarından beri, doğal kaynaklı bazı maddelerin alınmasına bağlı olarak sağlıklarının bozulacağını bilirler. İşte bu tür maddelere "zehir" (bitkisel, mineral, hayvansal veya sentetik) ve bu maddelere bağlı organizmada görülen geçici veya sürekli bozukluklara da "zehirlenme" adı verilir. Daha kapsamlı bir ifadeyle zehir; herhangi bir yol ile, nispeten yüksek miktarda tek veya tekrarlayan seferlerde ya da küçük miktarlarda uzun süre ile vücuda alındığında, ya anında ya da uzun bir süreçte geçici veya kalıcı hasar oluşturan ve hatta ölüme yol açabilen maddeler (toksik maddeler) olarak tanımlanır. XVI. yüzyılda Paracelsus kitabında; "Her madde zehirdir. Zehir olmayan madde yoktur; zehir ile ilacı ayıran onun dozudur" ifadelerine yer vermiştir.

Anahtar Kelimeler: Akut, ÖD50, zehir, zehirlilik denemeleri.

\section{ACUTE TOXIC TRIALS and LETHAL DOSE 50}

\begin{abstract}
People know that from the moment they exist, their health deteriorates by taking various harmful substances in nature into their bodies. Here is what disrupts human health; these substances of mineral, vegetable, animal or synthesis origin are called "poison" and the temporary or permanent deterioration of the organism with them "poisoning". To put it more comprehensively, poison; It is also defined as chemical substances (toxic substances) that can cause immediate or long-term temporary or permanent organism disorders and can lead to death when they enter the organism one or more times in relatively high doses or in small doses for a long time. XVI in the century Paracelsus used the expression "All things are poison, and nothing is without poison, the dosage alone makes it so a thing is not a poison".
\end{abstract}

Keywords: Acute, $\mathrm{LD}_{50}$, toxic, toxic trials. 


\section{GIRIS}

Zehirlilik denemeleri; canlıların belirli süre ya da süresiz herhangi bir maddeye veya metabolitine maruz bırakılmasına bağlı olarak gelişen istenmeyen etkilerin (görevsel, biyokimyasal veya yapısal istenmeyen etkiler gibi) nitel ve nicel olarak değerlendirilmesi esasına dayanır. Aslında bu denemeler, farmakolojik ve toksikolojik etkileri incelenen maddelerin, sağllklı hayvanlar üzerindeki etkilerinin araştırılmasını ve incelenmesini amaçlar. $\mathrm{Bu}$ testler; aynı görev veya metabolik yolu paylaşan hücrelerin belirli bir maddeye karşı benzer davranacağı, farklı görev veya metabolik yolu paylaşan hücrelerin ise yine belirli bir maddeye karşı farklı davranacağı ilkesine dayanır. Bu amaç için de genellikle; deney hayvanı olarak, hem anatomik hem de fizyolojik yönden insanlara yakınlığı sebebiyle sıçan (rat) ve köpek tercih edilir. Deneme hayvanlarında görülen etkiler birbirine benzerlik gösteriyorsa; bu etkilerin diğer hayvan türleri ile insanda da görülebileceği kabul edilir. Yalnız, sitokrom P450 aktivitesi gibi metabolik olayların küçük hayvanlarda daha hızlı olması sebebiyle, bu hayvanlarda görülen etkiler ile diğer canlılarda görülen etkilerin aynı olması mümkün değildir. $\mathrm{Bu}$ sebeple küçük hayvanlarda yapılan çalışmalarda elde edilen verilerin, insanlara uyarlanmasinda güven faktörü diye ifade edilen çeşitli oranların uygulanması zorunludur (Kaya ve ark., 2000; Nevin, 2005; Yarsan, 2013; Yavuz, 2020).

Zehirliliğin değerlendirilmesinde; dozyoğunluk-etki ilişkisi dikkate alınan en önemli faktör olmakla birlikte, etkisi araştırılacak olan maddenin kullanım amacı ve kullanım süresi gibi faktörlerde önemlidir. $\mathrm{Bu}$ sebeple zehirlilik denemeleri incelenen maddeye maruziyete göre; "tek" veya "tekrarlanan doz" uygulamalar olarak ayrilır. Tek doz zehirlilik denemeleri "Akut"; tekrarlanan doz zehirlilik denemeleri ise "Subakut", "Kronik", "Subkronik" ve "Diğer denemeler" diye sınıflandırılır. Etkisi araştırılan madde, eğer kısa süre kullanılacaksa bu testlerden akut ve subakut denemeler; uzun süre kullanılacaksa da bu denemelerle birlikte subkronik ve kronik denemeler tercih edilir. Bunlardan tek doz zehirlilik denemeleri; kimyasal bileşikler için öncelikle gözlenmesi gerekli olan, biyolojik etkileri ve zehirlenme belirtilerini ortaya koyabilmek amacıyla başvurulan başlıca test seçeneğidir. $\mathrm{Bu}$ test seçeneğinde deney hayvanlarına büyük bir sıklıkla tek doz halinde veya en fazla iki doz halinde verilen kimyasal bileşiğin oluşturduğu yanıtlar (etkiler) esas alınır. Belirtilen test, parenteral yollarla veya ağızdan verilen kimyasal maddenin oluşturduğu klinik akut zehirlenme belirtilerini gözlemlemek ve elde edilen sonuçlara göre Öldürücü Doz 50 (ÖD50) değerini saptamak esasına dayanır. Yeni geliştirilen kimyasal bir bileşiğin veya ilacın zehirliliğinin araştırılmasında ilk ve en önemli aşamayı oluşturur. Genellikle bu çeşit testlerde otopsi yapılmaz ve kontrol niteliğinde deney hayvanı kullanılmaz. Ama denemeye alınan kimyasal maddenin deney hayvanlarına uygulanabilmesi için çözücü veya taşıt madde olarak başka çeşit yabancı kimyasal maddelerin kullanılması söz konusu olduğunda, böyle yardımcı veya katkı maddelerinin muhtemel zehirliliğini de belirleyebilmek amacıyla, yalnızca aynı maddenin uygulandığı kontrol grubu oluşturulur. Tekrarlanan doz denemeler ise; hayvanların incelenecek olan maddeye kısa-orta veya uzun süre ile maruziyeti sırasında ya da sonrasında oluşabilecek fizyolojik, patolojik, biyokimyasal değişiklikleri incelemek amacıyla yapılır. $\mathrm{Bu}$ denemelerden subakut ve subkronik zehirlilik denemeleri, kısa-orta süreli tekrarlanan 
denemeler diye de bilinir (Şahan, 2003; Nevin, 2005; Yarsan, 2013; Kaya, 2014; Yavuz, 2020).

\section{Zehirlilik Denemeleri}

Zehirlilik denemeleri; zehirlenme tipine göre 5 ana başlık (akut, subakut, subkronik, kronik ve özel zehirlilik denemeleri) altında incelenir. Bu testlerde incelenen maddenin vücuttaki hareketine, etkilerine, zehirlenme durumlarında sağaltım seçeneklerine ve biyolojik ortamlardaki düzeylerinin (kalıntı durumuna) belirlenmesine yönelik çalışmalar da yapılır. Zehirlilik denemelerinin çalışma planı yapılırken bazı noktalara özen gösterilmesi gerekir. Bu bağlamda özellikle; etik kurul onayının alınması, 4R kuralına (Başka yöntem kullanma "Replacement", Azaltma "Reduction", İyileștirme "Refinement" ve Sorumluluk "Responsibility") riayet edilmesi, çalışma amacının tam olarak belirlenmesi ve gerekçelendirilmesi, uygun doz ve gerekirse doz aralığının belirlenmesi, araştırılacak etken madde ve denemelerde kullanılacak kimyasalların saflığı, uygun bakım ve besleme şartlarının oluşturulması, deneklerin belirli periyotlarla kontrol edilmesi, örneklemin uygun belirlenmesi ve uygun bir şekilde temin edilmesi gibi hususlar oldukça önemlidir (Nevin, 2005; Yarsan, 2013; Kaya, 2014; Yavuz, 2020).

\section{Akut Zehirlilik Denemeleri}

Bir maddenin toksisite potansiyeli hakkında bilgi edinmek için yapılması gereken bir testtir. Bu amaçla da en sık tercih edilen akut zehirlilik testi, letalite testi (öldürücü doz)'dir. Burada amaç; araştırılacak olan maddeye maruziyeti takiben görülebilecek toksik semptomları, hayati öneme sahip (beyin, karaciğer, böbrek gibi) belli başl1 organların etkilenme düzeyleri ve nihayetinde de letalite değeri diye de bilinen öldürücü dozu tespit etmektir. Aslında belirlenen bu öldürücü doz; bize, o maddenin hangi ölçüde güvenle kullanılabileceğini de gösterir. Genellikle bu denemelerde, kolay temin edilebilen ve maliyeti düşük olan fare veya sıçan gibi deney hayvanları tercih edilir. Buradan elde edilen değerlere göre, tavşan veya kobay gibi deney hayvanları kullanılarak, test tekrarlanabilir (Dökmeci, 1980; Eaton ve ark., 1996; Kaya, 2014; Yavuz, 2020). Bu amaçla kullanılacak hayvanlarının sağlıklı olması zorunludur. Ayrıca bu testlerde kullanılacak hayvanların uygulamadan önce ortama uyum sağlamaları gerekmekte olup, fare ve sıçan gibi küçük hayvanlar için en az 7 gün, köpek gibi daha büyük hayvanlar için ise en az 21 gün gözetim altına alınması önerilir (Eaton ve ark., 1996).

\section{Subakut Zehirlilik Denemeleri}

Subakut zehirlilik testleri; tekrarlayan doz zehirlilik denemeleri içerisinde değerlendirilir ve deneme süresi de genellikle 2 ila 4 hafta arasındadır. Bu uygulamada genellikle yem içerisine katılarak (oral yol) farklı dozlarda (3 veya 4) uygulanan etken maddenin zehirliliği irdelenir. Deney süresi sonunda kimyasal ve histopatolojik incelemeler ile klinik bulgular değerlendirilir. Subakut zehirlilik denemeleri 2 farklı türde (genellikle sıçan ve köpek) uygulanır. $\mathrm{Bu}$ denemeler; hem maddeye tekrarlanarak maruz kalınması durumunda oluşacak etkiler hakkında bilgi edinmek hem de subkronik zehirlilik denemelerinde kullanılacak dozu belirleyebilmek amacıyla gerçekleştirilir (Kaya, 2014).

\section{Subkronik Zehirlilik Denemeleri}

$\mathrm{Bu}$ testler, araştırılacak olan etken maddeye karşı deney hayvanlarının subkronik maruziyeti sonrasında görülebilecek etkilerin araştırılmasını amaçlar ve genellikle de 90 gün (1 ila 3 ay arasında 
da olabilir) sürer. Subkronik zehirlilik testi subakut testlerde olduğu gibi 2 farklı türde (genellikle sıçan ve köpek) ve genellikle yem içerisine katılarak (oral yol) farklı dozlarda (genellikle 3 farklı doz) olacak şekilde gerçekleştirilir. Bu 3 farklı doz da; yüksek doz (deney hayvanlarının \% 10 'dan fazlasını öldürmeyen miktar); düşük doz (görülebilir herhangi bir etkiye yol açmayan doz) ve ara doz (bu iki doz arasında seçilen bir doz) olacak şekilde belirlenir (Kaya, 2014).

Subkronik zehirlilik testleri süresince deney hayvanları, incelenen maddenin özellikle hayati öneme sahip olan organlar (beyin, karaciğer, böbrek gibi) üzerindeki olası etkileri yönüyle çok dikkatli bir şekilde gözlemlenmelidir. Özellikle bu son iki zehirlilik deneme testi ile (subakut, subkronik) günlük yaşantımızda maruz kalabileceğimiz maddelerin, insan sağlığına yönelik oluşturması muhtemel potansiyel risklerini de belirlemek mümkündür. $\mathrm{Bu}$ amaç için yapılan "risk tayini”; araştırılan etken maddenin "tanımlanması" ile başlayan bir süreçte, "doz-etki-cevap ilişkisi”, "maruziyet tayini” ve "risk karekterizasyonu" olmak üzere dört ana başlık altında gerçekleştirilir (Nevin, 2005; Kaya, 2014).

Subkronik zehirlilik denemeleri; hayvanlarda görülebilir etkiye yol açmayan en yüksek madde miktarını (NOEL, NEL) belirlemek, hedef doku, organ veya sistemlerin etkilenme derecesini ortaya koymak, tekrarlanan maruziyet durumlarında dozetki ilişkisini değerlendirmek ve kronik zehirlilik denemeleri için doz belirlemek amacıyla yapılır (Kaya, 2014).

\section{Kronik Zehirlilik Denemeleri}

Kronik zehirlilik testleri; araştırılan etken maddenin, deney hayvanının hayatının önemli bir bölümünde ve hatta bir-iki jenerasyon süresince maruz kalması sonucunda oluşturduğu etkileri araştırmayı amaçlar. Kronik zehirlilik denemeleri; süresinin uzun olması dışında subkronik zehirlilik testleri gibidir. Bu süre; rodentler için 6 ay ila 2 yıl, diğer türler içinse 1 y1l ve hatta daha da uzun olabilir. $\mathrm{Bu}$ sürenin belirlenmesinde, araştırılacak etken madde göz önünde bulundurulur. Örneğin; araştırılacak madde ilaç ise 6 aylık bir süre yeterli iken, araştırılacak madde besin katkı maddesi ise en az 2 yıllık bir süre düşünülmelidir (Şahan, 2003; Viau, 2003).

Kronik zehirlilik testleri ile doz cevap ilişkisinden de yararlanılarak; görülebilir etkiye yol açabilen en küçük miktar (LOEL), görülebilir zararlı etkiye yol açan en küçük miktar (LOAEL), görülebilir etkiye yol açmayan en yüksek miktar (NOEL) ve görülebilir zararlı etkiye yol açmayan en yüksek miktar (NOAEL) değerleri hesaplanabilir (Dökmeci, 1980; Kaya, 2014).

\section{Özel Zehirlilik Denemeleri}

Özel zehirlilik denemeleri; karsinojen-mutajenteratojen etki denemeleri, gelişme ve üreme sistemi üzerine etki denemeleri ile diğer maddelerle etkileşme denemelerini kapsar. Bu grup testler, özellikle gıdalarda kalıntıya yol açabilen ilaçlar, gıda katk1 maddeleri, zirai mücadelede kullanılan maddeler, halk sağlığı veya çevre sağlığının korunmasında kullanılacak maddeler için oldukça önem taşır. $\mathrm{Bu}$ amaçla incelenecek etken maddelerin, tüm biyolojik sistemler ve etkiler dikkate alınarak, ömür boyu mutajenik ve karsinojenik incelemeler, teratojenik etkili maddeler için de en az üç nesilde yedirme veya kullanma denemeleri yapılır. Üreme ve gelişmeye yönelik zehirlilik denemelerinde, belirli protokoller çerçevesinde kısa ve uzun süreli, genellikle 3-4 dönemli hayvan denemeleri yapılır. $\mathrm{Bu}$ denemelerden ilk üçü kısa süreli, dördüncüsü ise 
uzun süreli denemelerdir ve en az üç nesil devam ettirilir (Kaya, 2014; Yarsan, 2013; Yavuz, 2020).

\section{Zehirlilik Denemelerinin Tarihsel Gelişimi}

Hayvanlar üzerinde yapılan deneysel işlemlere dair en eski kayıtlar, MÖ. 2. yy.’a kadar uzanan Yunan metinlerine aittir. $\mathrm{Bu}$ kayitlara göre, hayvanlar üzerinde deney yapan ilk bilim insanları olarak Aristo ve Erasistratus kabul edilir. Yine 2. yy'da Roma'da hekimlik yapan ve "dirikesimin atası" olarak da kabul edilen Galen; domuz ve keçiyi deney hayvanı olarak kullanmıştır (Gallo, 2001; Gilles, 2003).

Aslinda hayvanlar, tarih boyunca bilimsel araştırmalarda sıklıkla kullanılmıştır. Louis Pasteur 1880'lerde “mikrop teorisi”ni ispat etmek amaciyla koyunlara şarbon etkenini vermiş ve başarılı olmuştur. Ivan Pavlov ise 1890'larda klasik şartlanmayı açıklamak amacıyla köpekleri kullanmıştır. Yine 1922'de insülin ilk köpeklerden yalıtılmış, ilerleyen süreçte kullanıma girmesiyle de şeker hastalığı sağaltımında bir devrim yaratmıştır. 1970'lerde armadilolar kullanılarak; cüzzam hastalığının aşılar ve antibiyotikle tedavi seçeneği geliştirilmiş, ardından da bu aşı ve antibiyotikler insanlara uygulanmıştır (Gallo, 2001; Gilles, 2003).

Günümüzde basit omurgalılardan gelişmiş memelilere kadar pek çok canl,, denek olarak kullanılır. Bu hayvanlar içerisinde de en fazla tercih edilenler; sıçan, fare, kobay, hamster, tavşan, balık, domuz, köpek ve maymun'dur.

\section{Zehirlilik Denemeleri ile İlgili Yasal Düzenlemeler}

Toksikoloji bilimi aslen 20. yüzyılda önem kazanmıştır. Yirminci yüzyıla kadar ilaç kullanımına yönelik düzenlemeleri içeren kanunlar oldukça esnektir. Örneğin; 1937 y1lına kadar ABD'de yetkili otorite bir ilacı ancak ilacı kullananlara karşı zarar verdiği mahkemece onaylandıktan sonra yasaklayabiliyordu. $\mathrm{Bu}$ tarihte, "Elixir of Sulfanilamid" isimli bir ilacın yüzden fazla ölüme sebep olması üzerine, ABD kongresi tarafindan "ilaçların satı̧a arzından önce hayvanlar üzerinde bazı güvenlik testlerine tabi tutulması" zorunlu hale getirilmiştir (Richard, 2001).

Zehirlilik denemeleri ülkelerin yasama organları tarafindan düzenlenmesi ile birlikte, karşımıza "Regulatory Toxicology" ifadesi çıkmıştır. Zehirlilik denemeleri ve risk tayini testlerinin en önemli amacı, daha önce de ifade edildiği gibi, araştırılan etken maddenin insanlar ve biyoekosistem üzerinde herhangi bir olumsuz etki oluşturmayacağı şartların belirlenmesidir (Richard, 2001). Bu amaçla her ülke kendine özgü, yarg1 ve yürütmeye ilişkin yasal düzenlemeler oluşturmuştur. Örneğin, ABD'nde EPA, FAO, OSHA gibi kuruluşlar bu amaca yönelik hizmet verirken; ülkemizde ise konuyla ilgili olarak Çevre Kanunu; Umumi Hıfzısıhha Kanunu, Su Kirliliği Kontrol Yönetmeliği, Hava Kalitesinin Korunması Yönetmeliği, Gıda Maddelerinin ve Umumi Sağlığı İlgilendiren Eşya ve Levazımın Hususi Vasıflarını Gösteren Tüzük, Radyasyon Sağlığı ve Güvenliği Tüzüğü, İşçi Sağlığı ve İş Güvenliği Tüzüğü gibi kanun, yönetmelik ve tüzükler yürürlüktedir. Yine ülkemizde zehirli maddelere yönelik uluslararası kuruluşlar (WHO, FAO, EEC, OECD gibi) tarafindan oluşturulmuş düzenlemeler de yürürlüktedir (Nevin, 2005).

\section{Akut Zehirlilik Denemeleri ve ÖD50}

Akut zehirlilik denemeleri, deney hayvanlarma araştırılan maddenin tek doz uygulanmasından sonra alınan doz-etki-cevap ilişkisini değerlendirmeyi amaçlar ve bu denemeler ile araştırılan maddenin 
akut zehirliliği, bunun için de öncelikle de Öldürücü

Doz 50 (ÖD50 veya ÖY ${ }_{50}$ ) değeri belirlenir. Ayrıca bu denemeler kapsamında, araştırılan maddenin diğer akut zehirli etkileri de (deri ya da göze olan irritan etki, balıklar için su ile maruziyet gibi) incelenir (Kaya ve ark., 2000; Nevin, 2005; Yarsan, 2013; Yavuz, 2020).

ÖD 50 değeri; “deney hayvanlarına araştırılan maddenin tek doz uygulanmasını takiben, belirli bir süre içerisinde (genellikle bu süre 24 saattir) ve uygulanan hayvan popülasyonunda $\% 50$ oranında ölüme yol açan dozu"nu ifade eder ve birimi vücut ağırlığına göre "miktar madde/kg" ya da birim vücut yüzeyine göre "miktar madde $/ \mathrm{cm}^{2}$ " şeklindedir. Burada verilen miktar madde değeri; katı özelliğe sahip etken maddeler için ağırlık ( $\mu \mathrm{g} / \mathrm{kg}$ veya $\mathrm{mg} / \mathrm{kg}$ gibi), sıvı özelliğe sahip etken maddeler içinse ağırlık veya hacim $(\mu \mathrm{g} / \mathrm{kg}$ veya $\mathrm{mg} / \mathrm{kg}$ ya da $\mu 1 / \mathrm{kg}$ veya $\mathrm{ml} / \mathrm{kg}$ gibi) olarak ifade edilir. Solunum yolu ile inhalasyon şeklinde uygulanan gaz özellikli etken maddeler içinse, ppm veya ppb gibi belirli bir hacimdeki hava içerisinde bulunan madde yoğunluğunu ifade eden birimler ya da $\mu \mathrm{g} / \mathrm{m}^{3}$ hava veya $\mathrm{mg} / \mathrm{m}^{3}$ hava gibi birimler kullanılır (Kaya ve ark., 2000; Nevin, 2005).

ÖD50 değeri ilk olarak Trevan tarafından 1927 yılında ortaya atılmıştır. Bu değer bireysel ve dış faktörlerden oldukça etkilenen bir değerdir ve kesin sonuç alınabilmesi için çok sayıda deneğe gereksinim duyulur. Hayvan refahı ve etik ilkelerden hareketle günümüzde bu testlere yönelik ağır eleştiriler olsa da, araştırılan etken maddelerin zehirliliklerine ilişkin pek çok noktada bu değerin hesaplanması gerekliliği vardır. Bu nedenle de halen doz-etki-cevap ilişkisinin irdelenmesi ve semptomolojisinin araştırılması noktasında temel değerlerden biri konumundadır (OECD, 2001).
Günümüzde grafiksel yöntem, ÖD değerinin belirlenmesi amacıyla kullanılan en basit yöntem olup; hep ya da hiç prensibine dayalı kuvantal etki düşüncesinden hareket eder. Böylelikle oluşturulan farklı deney gruplarında, artırılmış doza karşı oluşan cevap (ki bu notada oluşan cevap ölüm'dür) yüzdesi ve bu yüzdeye karşılık gelen normal dağılımda oluşan kümülatif etkinin değerlendirilmesi amaçlanır (Şahan, 2003; Nevin, 2005). Kuvantal denemelerde ÖD $\mathrm{D}_{50}$ değerinin hesaplanmasına ilişkin kullanılabilecek yöntemler; grafik yöntemi, interpolasyon yöntemi, probit analizi, logit analizi, Dragstedt-Behrens yöntemi, Karber yöntemi, Spearman-Karber yöntemi, Trimmed Spearman-Karber yöntemi, Miller-Tainter yöntemi, Red-Muench yöntemi, Thompson hareketli ortalama yöntemi, Shuster-Dietrich yöntemi, Shuster-Yang yöntemi, Robbins-Monro yöntemi, yukarı (up) - aşağı (down) yöntemi ve Lorke yöntemidir (Doğan ve Doğan, 2015).

Elbette ki deney hayvanları üzerinde yapılan akut zehirlilik denemelerinden elde edilen veriler, direkt olarak insanlarda oluşabilecek riskleri öngörmede kullanılacak olan veriler olarak kullanılamayacaktır. $\mathrm{Bu}$ noktada araştırılan etken maddenin çalışılan deney hayvanındaki bulunan ÖD 50 değeri, farklı bir tür canlıdaki ÖD 50 değerinden ayrı olacaktır. Hatta bu değerler arasında on kata varan oranlarda fark oluşabilir. Örneğin metilfloroasetat'ın ÖD 50 değeri, köpekler için 0,15 $\mathrm{mg} / \mathrm{kg}$ iken, maymunlar için $11 \mathrm{mg} / \mathrm{kg}$ 'dır (Loomis, 1978). Hatta birbirine çok yakın olan hayvan türleri arasında bile bu oranlara varan ölçekte fark görülebilir. Örneğin; hamster ve fareler için parasetamol'ün ÖD 50 değeri 250 ila 400 mg/kg arasında ve ölüm nedeni bu hayvanlarda karaciğerde oluşan hasara bağlıyken; bu değer sıçanlar için 1000 
$\mathrm{mg} / \mathrm{kg}$ düzeyindedir ve sıçanlarda karaciğere yönelik olumsuz bir etkisi de görülmemiştir. Benzer şekilde; Hopkins sıçanlarında tiyoüre'nin ÖD50'si 4 mg/kg'ken; Norwegian sıçanlarında bu değer 1340 $\mathrm{mg} / \mathrm{kg}^{\prime}$ dır. ÖD 50 değerine tür farkının yanında sicaklık ve nem gibi fiziksel etkilerle birlikte cinsiyet, yaş, sosyal ortam ve beslenme de etki edebilir ki bu etki bazen 8-14 kata varan oranda fark oluşmasına da yol açabilir. İşte bu sebeple, deney hayvanları üzerinden elde edilen $\mathrm{ÖD}_{50}$ değeri insanlara uyarlanırken mutlaka bir güven faktörüne tabi tutulur ve bu güven faktörünün de 1000 hatta 10000 olarak seçilmesi önerilir (Eaton ve ark., 1996; Vildan ve ark, 2016).

Bazı maddelerin fare, sıçan, tavşan ve insandaki ÖD değerleri Tablo 1'de; Hodge ve Sterner Skalasina göre toksisitenin derecelendirilmesi ise Tablo 2'de verilmiştir.

Tablo 1. Bazı maddelerin fare, sıçan, tavşan ve insandaki ÖD değerleri.

\begin{tabular}{lllll}
\hline Madde & İnsan için ÖD & Sıçan ÖD & Fare ÖD & Tavşan ÖD \\
\hline Kafein & $192 \mathrm{mg} / \mathrm{kg}$ & $192 \mathrm{mg} / \mathrm{kg}$ & $620 \mathrm{mg} / \mathrm{kg}$ & - \\
Borik asit & $640 \mathrm{mg} / \mathrm{kg}$ & $2660 \mathrm{mg} / \mathrm{kg}$ & $3450 \mathrm{mg} / \mathrm{kg}$ & - \\
Lindan & $840 \mathrm{mg} / \mathrm{kg}$ & $125 \mathrm{mg} / \mathrm{kg}$ & - & $130 \mathrm{mg} / \mathrm{kg}$ \\
Amital & $43 \mathrm{mg} / \mathrm{kg}$ & $560 \mathrm{mg} / \mathrm{kg}$ & - & $570 \mathrm{mg} / \mathrm{kg}$
\end{tabular}

Tablo 2. Hodge ve Sterner Skalasına göre toksisitenin derecelendirilmesi.

\begin{tabular}{|c|c|c|c|c|}
\hline Toksisite derecesi & $\begin{array}{l}\text { Oral ÖD } 50 \text { mg/kg } \\
\text { (Tek doz) }\end{array}$ & $\begin{array}{l}\text { Solunum ÖY } 50 \text { ppm } \\
\text { (4 saat maruziyet) }\end{array}$ & $\begin{array}{l}\text { Deri ÖD50 mg/kg } \\
\text { (Tek uygulama) }\end{array}$ & $\begin{array}{l}\text { İnsan için } \\
\text { muhtemel ÖD }\end{array}$ \\
\hline 1. Son derece Toksik & $<1$ & $<10$ & $<5$ & Bir damla \\
\hline 2. Şiddetli Toksik & $1-50$ & $10-100$ & $5-43$ & $4 \mathrm{ml}$ \\
\hline $\begin{array}{l}\text { 3. Orta derecede } \\
\text { Toksik }\end{array}$ & $50-500$ & $100-1000$ & $44-340$ & $30 \mathrm{ml}$ \\
\hline 4. Az Toksik & $500-5000$ & $1000-10.000$ & $350-2810$ & $600 \mathrm{ml}$ \\
\hline $\begin{array}{l}\text { 5. Pratik Olarak } \\
\text { Toksik Değil }\end{array}$ & $5000-15.000$ & $10.000-100.000$ & $2820-22.590$ & 1 litre \\
\hline $\begin{array}{l}\text { 6. Rölatif Olarak } \\
\text { Zararsız }\end{array}$ & $>15.000$ & $>100.000$ & $>22.600$ & 1 litre \\
\hline
\end{tabular}

ÖD 50 tayinde sıklıkla kullanılan diğer bir yöntem; Karber - Behrens yöntemidir ve istatistiksel hesaplamalar ile oluşturulmuş olan bir formüle göre hesaplanır (Tablo 3) (Nevin, 2005).
$\ddot{O ̈ D}_{50}=\ddot{O} D_{100}-(\mathbf{a b}) / \mathbf{n}$

a: Takip eden iki doz arasındaki fark;

b: Takip eden iki dozdan ileri gelen ölümlerin aritmetik ortalamasi;

n: Gruptaki hayvan sayıs1;

ÖD 100 : Tek doz uygulamada deney hayvanlarının \% 100’ünü öldüren doz. 
Tablo 3. Karber-Behrens yöntemine göre ÖD 50 'nin hesaplanması (Nevin, 2005).

\begin{tabular}{|c|c|c|c|c|c|c|}
\hline Grup & $\begin{array}{l}\text { Gruptaki hayvan } \\
\text { sayısı (n) }\end{array}$ & $\begin{array}{l}\text { Dozlar } \\
\text { mg/kg }\end{array}$ & $\begin{array}{l}\text { Ölüm } \\
\text { sayısı }\end{array}$ & a & b & ab \\
\hline I & 10 & 15 & 0 & 5 & & \\
\hline II & 10 & 20 & 2 & $5^{J}$ & 1 & 5 \\
\hline III & 10 & 25 & 4 & ${ }_{5}^{1}$ & 3 & 15 \\
\hline IV & 10 & 30 & 8 & $\left.{ }_{5}\right]$ & 6 & 30 \\
\hline $\mathrm{v}$ & 10 & 35 & 9 & ${ }_{5}^{]}$ & 8.5 & 42.5 \\
\hline VI & 10 & 40 & 10 & ${ }_{5}^{]}$ & 9.5 & 47.5 \\
\hline
\end{tabular}

\section{Frekans cevap (Kuvantal doz-cevap) ilişkisi:}

Deneysel olarak, aynı tür içerisinde ve aynı dozda uygulanan bir maddeye karşı alınan cevap değişikliğinin, normal Gaussian dağılımına uyduğu gösterilmiş̧ir. Böylelikle deney hayvanlarına uygulanan her doz aralığında alınan cevap \%'lerinin (ÖD $\mathrm{D}_{50}$ 'de alınan bu cevap, ölümdür) grafiğe aktarılması sonucunda elde edilen "kuantal dozcevap ilişkisi” normal bir Gaussian dağılımı gösterir. Yine benzer şekildeki histogramda ise her kolon, doz aralığında (uygulanan müteakip iki doz arasındaki deney gruplarında görülen \% ölüm fark) ölen hayvanların \% değerini verir. Elde edilen bu \%'lik cevap, bize ölüm sıklığını (frekansını) verir. Aynı türde, hatta aynı soyda bile çeşitli nedenlere bağlı olarak, normal bireylere oranla daha farklı cevaplar da görülebilir. Değerlendirmede, uygulanan maddeye düşük dozda yanıt veren hayvanlar "Aşırı duyarlı ya da Hipersensitive"; yüksek dozda yanıt veren hayvanlar ise "Dayanıklı ya da Rezistant" bireyler olarak değerlendirilebilir (Amadou, 2005; Amiard, 2011).

Doz-probit ilişkisi: Uygulama sonrasında elde edilen doz-cevap ilişkisinde, doza karşı verilen cevap (ki burada bu cevap, ölümdür), "Probit birimi” olarak da ifade edilebilir. İstatistik değerlendirmelere göre; $\mathrm{ÖD}_{50} \pm 1$ SD (SD: Standard sapma) bize o topluluğunun $\% \quad 68,3$ 'ünü; $\quad \mathrm{ÖD}_{50} \pm 2 \quad \mathrm{SD} \quad$ o topluluğunun $\% 95,5$ 'ini ve $\mathrm{OD}_{50} \pm 3 \mathrm{SD}$ ise o topluluğunun \% 97,7'sini verir. Yine istatistik bilgilere dayanarak, normal bir dağılımda alınacak olan \% cevabın, normal eşdeğer sapma (NED) karşıllı̆ı da hesaplanabilir. Burada NED değeri negatif sayıları da içerebildiğinden, NED değeri üzerine 5 eklenerek elde edilen "Probit Birimi" $($ Probit Birimi $=$ NED değeri +5$)$ daha fazla tercih edilir. Özellikle Probit Birimi üzerinden hareketle elde edilen doz-cevap eğrisi, aynı Ö $\mathrm{D}_{50}$ değerine sahip maddelerin, diğer dozlarda gösterebilecekleri toksisiteyi karşış̧tırabilme imkanı vermesi açısından da önemlidir. Ayrıca, bu değer, ilaç güvenirliğinin saptanması amacıyla da kullanılır (Amiard, 2011).

$\mathrm{Bu}$ yöntemle $\mathrm{Ö}_{50}$ değerinin belirlenebilmesi için, çok sayıda deneğe (yaklaşık elli hayvan) ihtiyaç vardır. Bu sebeple hayvan refahı da gözetildiğinde, daha az denek kullanılarak gerçekleştirilen Ö $\mathrm{D}_{50}$ tayin yöntemleri (Karber - Behrens Yöntemi gibi), daha fazla tercih edilir (Amiard, 2011; Tülin, 2011).

Sağaltum indeksi (Terapötik indeks - Tedavi indeksi): Genel olarak bu değer, bir maddenin Öldürücü veya Zehirli dozu (ÖD $\left.{ }_{50}, Z_{50}\right)$ ile tedavide kullanılan dozunu $\left(\mathrm{ED}_{50}\right)$ mukayese etmek amaciyla kullanılır.

$$
\text { Sağaltım İndeksi (TI, SI) = ÖD50 }\left(\text { veya } Z_{50}\right) / \text { ED }_{50}
$$

$\mathrm{Bu}$ değer ne kadar büyükse, yani zehirli veya öldürücü doz ile tedavi amacıyla kullanılan doz arasındaki açıklık ya da fark ne kadar fazla ise, madde o kadar güvenlidir. Ayrıca Sİ değeri, maddelerin zehirliliklerini karşılaştırmak amacıyla da kullanılır. Bu değer 4 ve 4'ün altında ise, bu maddeler "tehlikeli" veya "Sİ dar" maddeler olarak değerlendirilir. Yalnız, bu değer tek başına, bir maddenin güvenilirliği için yeterli değildir. $\mathrm{Bu}$ 
amaçla Güvenilirlik Sınırı veya Güven Aralığı (Güvenlik Genişliği) diye ifade edilen (ÖD 1 ED99) bir başka değer daha kullanılır (Nevin, 2005; Amiard, 2011; Kaya, 2014).

Akut zehirlilik denemeleri içerisinde; akut deri veya solunum yolu ile koklatma, deri ve mukozalar için irkiltici etki ve aşırı duyarlılık denemeleri de yer alır (Kaya, 2014).

\section{SONUC}

Halen günümüzde, özellikle yeni geliştirilen ilaçlar başta olmak üzere, günlük yaşamımızda kullanabileceğimiz kimyasal maddelerin güvenilirliğinin belirlenmesi amacıyla yapılan zehirlilik denemeleri oldukça önem arz eder. Zehirlilik denemeleri ile aynı zamanda araştırılan etken maddelerin organizmada nasıl yıkımlandığ 1 ve etken maddeye karşı verilen cevapta oluşan bireysel farklılıkların mekanizması da araştırılabilir. Elbette buradan elde edilen verilerin insanlara uyarlanmasında mutlaka belli güvenlik faktörleri kullanılır; ancak, bu amaçla yapılacak uyarlamalar da her zaman geçerli veya tutarlı olmayabilir. Ayrıca bu amaç için yapılan zehirlilik denemelerinde kullanılan canlı sayısı bazen binleri bulabilir ve bu canlılar da uygulamalar esnasında ciddi acılar çeker. $\mathrm{Bu}$ sebeple de, son zamanlarda çeşitli insan doku kültürleri, omurgasız canlılar veya embriyonik yumurta kullanımı ve bilgisayar programları gibi alternatif yöntemler geliştirilmiştir. Ancak bu yöntemlerin de; in vitro yapılan denemelerin tek başına sistemik zehirliliği araştırmakta yetersiz olarak değerlendirilmesi sebebiyle, in vivo testler için bir ön tarama çalışması olarak kabul görmesi noktasındaki tartışmalar halen devam etmektedir. İlerleyen süreçte, bu alternatif yöntemlerin daha da geliştirilerek, deney hayvanı kullanımının daha da sinırlandırılması beklenmektedir.

\section{KAYNAKLAR}

Amadou, D. (2005). Etudes de la Phytochimie et des Activités Biologiques de Syzygium guineense Willd (MYRTACEAE). Université de Bamako, These doctorale.

Amiard, M. (2011). Détermination d'une dose critique $\left(\mathrm{DE}_{50}, \mathrm{DL}_{50}, \mathrm{CL}_{50}, \mathrm{NOAEL}\right.$ et LOAEL). Université de Nantes.

Ayhan, F., Begüm, Y.D., Kuzukıran, Ö. (2016). Balık Tosikolojisi, Türkiye Klinikleri J Vet Sc1 Pharmacol Toxicol Special Topics. 2(1), 69-84.

Canadian Centre for Occupational Health and Safety (2018). What does $\mathrm{LD}_{50}$ mean? What does $\mathrm{LC}_{50}$ mean? Why study LD50's. Erişim Adresi: http://www.ccohs.ca/oshanswers/chimicals/ld50.h tml. Erișim Tarihi: 05/09/2018.

Doğan, İ., Doğan, N. (2015). İki Sonuçlu Biyolojik Denemelerde LD50 Değerinin Tahmininde Kullanılan İstatistiksel Yöntemler. Turkiye Klinikleri J Biostat,7(1), 39-46.

Dökmeci, İ. (1980). Akut toksisite yöntemleri. Trakya Tıp Fakültesi Dergisi, 2(2), 126-132.

Eaton, D., Klaassen, C. (1996). Principles of Toxicology, In, C Klaassen (ed), Caserett and Doull's Toxicology: the Basic Science of Poisons, New York: McGraw-Hill.

Gallo, MA. (2001). History and scope of toxicology. In, Klaassen CD (ed), Caserett and Doull's Toxicology: the Basic Science of Poisons (5th ed), News York: McGraw Hill.

Gilles, L. (2003). Notions de Toxicologie. Universites de Nantes, Cours de toxicologie, 1-29.

Kaya, S. (2014). Veteriner Toksikoloji, Bask1 3. Medisan Yayınevi, Ankara, 17-26.

Kaya, S., Pirinç, İ., Bilgili, A. (2000). Veteriner Hekimliğinde Toksikoloji, Baskı 2. Medisan Yayınevi, Ankara, 21-32.

Loomis, TA. (1978). Essentials of Toxicology, 3rd edition, Philadelphia, Lea and Febiger, 157-232.

Nevin, V. (2005). Ankara Üniversitesi Eczacılık Fakültesi Yayınları, 13-19; 223-236.

OECD. (2019). Lignes directrices de l'OCDE pour les essais de produits chimiques. Poisson, essai de toxicité aiguë.Ligne directrice $n^{\circ} 203$.

OECD. (2001). Ligne Directrices de l'OECD pour les Essais de Produits Chimiques (toxicité orale aiguemothode par classe de toxicité aigue).

Richard, A. (2001). Regulatory toxicology. In, Klaassen CD, ed: Casarett and Dull's Toxicology. The basic Science of Poisons, 5th ed, 1140-1151.

Süheyla, T., Sevil, Y., Rıfat, Y. (2019). Bazı İlaç Gruplarının Su Ortamına Olan Etkilerinin Akut Toksisite Testleri ile Değerlendirilmesi. Süleyman Demirel University Journal of Natural and Applied Sciences Volume 23, Special Issue, 71-75.

Şahan, S. (2003). Deneysel Toksikolojide Toksisite Testleri ve Test Sonuçlarının Önemi. Gülhane Tıp Dergisi 45 (3), 291-298.

Tülin, D. (2011). Çinkonun Daphnia magna (Straus, 1820) (Crustacea: Cladocera) üzerinde akut toksik etkisinin araştırılması A.Ü/Fen B.Enstitüsü, Yüksek Lisans Tezi, 21-32. 
Viau, C. (2003). Enrironnement et Santé PubliqueFondements et Pratique, 1-27.

Vildan, Z.S., Nüket, S. (2016). Akut toksisite testi hassasiyetinin belirlenmesinde Referans Toksik Madde olarak Formaldehid kullanımı. Istanbul Üniversitesi, Çevre Mühendisliği Bölümü. Anadolu Çevre ve Hayvancılık Bilimleri Dergisi. 96-99.
Yarsan, E. (2013). Farmakoloji ve Toksikoloji Çalışmalarında Rat Modelleri. Laboratuvar Hayvanları Bilimi - 3. Ulusal Kongresi, Kayseri, 2013.

Yavuz, O. (2020). Zehirlenme ve zehirlilik denemeleri. Erişim Adresi: https://avys.omu.edu. tr/storage/app/public/oguzhany/119790/3.\%20Ze hirlenme\%20ve\%20Zehirlilik\%20Denemeleri.pdf Erişim Tarihi: 05/09/2020. 